\title{
NITROGEN AND NITRIDE NON-METALLIC INCLUSIONS IN STEEL
}

\author{
DUŠIK IN NITRIDNI NEKOVINSKI VKLJUČKI V JEKLU
}

\author{
Jaka Burja ${ }^{1}$, Mitja Koležnik ${ }^{2}$, Špela Župerl ${ }^{3}$, Grega Klančnik ${ }^{4,5}$ \\ ${ }^{1}$ Institute of Metals and Technology, Lepi pot 11, 1000 Ljubljana, Slovenia \\ ${ }^{2}$ SIJ Metal Ravne d. o. o., Koroška cesta 14, 2390 Ravne na Koroškem, Slovenia \\ 3 Štore Steel d.o.o., Železarska cesta 3, 3220 Štore, Slovenia \\ ${ }^{4}$ SIJ Acroni d.o.o., Cesta Borisa Kidriča 44, 4270 Jesenice, Slovenia \\ ${ }_{5}$ RCJ d.o.o., Cesta Franceta Prešerna 61, 4270 Jesenice, Slovenia \\ Prejem rokopisa - received: 2019-10-15; sprejem za objavo - accepted for publication: 2019-11-02
}

doi: $10.17222 /$ mit.2019.247

The paper deals with the formation of coarse nitride non-metallic inclusions in steel. The thermodynamic calculations for the determination of the equilibrium solubility of nitrogen in the steel melt at a given temperature and chemical composition are presented. Some of the negative effects of excessive nitrogen contents, like blow holes, strain aging and, most importantly, nitride non-metallic inclusion formation are discussed. Five types of the coarse nitride non-metallic inclusions that occur in industrial practice are presented: aluminium, boron, niobium, titanium, and zirconium nitrides. Examples of the negative effect of coarse nitrides from case studies are also shown. The basic thermodynamic tools and values of the parameters for calculating the nitride precipitation in the steel melt are given in the paper.

Keywords: non-metallic inclusions, steelmaking, nitrides, nitrogen in steel

V članku obravnavamo tvorbo grobih nitridnih nekovinskih vključkov v jeklu. Predstavljeni so termodinamski izračuni za določanje topnosti dušika v jekleni talini pri poljubni temperaturi in sestavi jeklene taline. Prikazali smo nekatere negativne vplive previsoke vsebnosti dušika v jeklu, kot so: nastanek plinske poroznosti, staranje in predvsem nastanek nitridnih nekovinskih vključkov. Predstavili smo pet tipov grobih nitridov, ki se pojavljajo v industrijski praksi. To so aluminijevi, borovi, niobijevi, titanovi in cirkonijevi nitridi. Prikazali smo tudi negativni vpliv grobih nitridov na lastnosti jekel. V članku smo podali osnovna termodinamska orodja in vrednosti parametrov za izračun izločanja nitridov v jekleni talini.

Ključne besede: nekovinski vključki, jeklarstvo, nitridi, dušik v jeklu

\section{INTRODUCTION}

The increasing demands for high-quality products have made the steelmaker increasingly aware of the steel "cleanliness" requirements. The mechanical properties of steel are affected by the volume fraction, size, distribution, composition, and morphology of non-metallic inclusions and precipitates, which can act as stress raisers. ${ }^{1,2}$ For example, fatigue properties, ductility and fracture toughness are known to be decreased by nonmetallic inclusions, especially in higher-strength, lower-ductility alloys. ${ }^{3-7}$

The most important parameters influencing clean steel production are the steel composition, the slag composition, the refractory lining, the melt processing, and the casting practice. ${ }^{1}$

The steel composition includes oxygen, nitrogen and sulphur levels in combination with oxide forming ( $\mathrm{Al}$, $\mathrm{Ca}, \mathrm{Si}, \mathrm{Mg} . .$.$) , nitride forming ( \mathrm{Ti}, \mathrm{Nb} . .$.$) and sulphide$ forming ( $\mathrm{Ca}, \mathrm{Mn}$...) elements. The slag composition includes basicity $\left(\mathrm{CaO}: \mathrm{SiO}_{2}\right)$ and some oxides, like $\mathrm{Al}_{2} \mathrm{O}_{3}$, $\mathrm{MgO}$ and $\mathrm{FeO}+\mathrm{MnO}$ (slag carryover). The refractory lining needs to be resistant to slag erosion (minimal

*Corresponding author's e-mail:

jaka.burja@imt.si (Jaka Burja) silica content); the refractory is the main source of $\mathrm{MgO}$ (causes spinel formation). The melt processing is of paramount importance to clean steel production. This includes the tapping practice (reoxidation, slag carryover), alloying (including deoxidation and modification) where the addition timing and amounts are important. Other secondary refining processes like melt stirring, desulphurisation, vacuuming (decreases oxygen, nitrogen and sulphur at once) decrease the amount of non-metallic inclusions. The casting practice is the final factor and it can have a detrimental effect. Firstly, there is an important difference between ingot (lower cleanliness) and continuous casting (higher cleanliness), then there are also accompanying processes and materials like electromagnetic mould stirring, argon shrouding of nozzles and mould flux that also greatly affect the final steel cleanliness.

The content of non-metallic inclusions is generally connected to the amount of total oxygen and sulphur in the steel, as oxides and sulphides commonly form the bulk of the non-metallic inclusions. The total oxygen in the steel is the sum of the free oxygen (dissolved oxygen) and the oxygen that is chemically bound in compounds (non-metallic inclusions). Free oxygen, or "active" oxygen, can be measured in molten steel using 
oxygen sensors (usually along with temperature measurements). The free oxygen is controlled by the equilibrium thermodynamics with deoxidation elements, such as aluminium and is usually low (3-5 $\mu \mathrm{g} / \mathrm{g})$. Because the free oxygen does not vary much, the total oxygen is a reasonable indirect measure of the total amount of oxide inclusions in the steel. ${ }^{1}$ Low oxygen and sulphur levels must be achieved to ensure low nonmetallic inclusion contents. This can be achieved with steelmaking practices, by properly refining the steel melt during the ladle treatment, using sufficient degassing times, vacuuming, etc. The presence of elements like aluminium, calcium, silicon, manganese, rare-earth metals, magnesium and zirconium has a profound effect on the non-metallic inclusion formation and related size, number, chemistry and morphology. ${ }^{8-13}$

Nitrogen, on the other hand, is often an overseen factor in the prediction of the non-metallic content. Specialized test methods cover a number of recognized procedures for determining the non-metallic inclusion content of steel, these methods are primarily intended for rating oxide and sulphide inclusions. But constituents such as carbides, nitrides, and carbonitrides may be rated by adopting some of the microscopic methods described in ASTM E45. ${ }^{14}$ This is probably due to the fact that only special alloying elements form nitride non-metallic inclusions. The fact is that all steels contain some nitrogen, which can enter the steel as an impurity or as an intentional alloying addition. Intentional nitrogen alloying includes stirring the melt with nitrogen gas and adding ferro-alloys with increased nitrogen, such as ferrochromium nitre $(4 \% \mathrm{~N})$ and nitrovan vanadium $(16 \% \mathrm{~N})$. However, numerous other less-desired sources of nitrogen (nitrogen pickup), and sometimes other gases (oxygen, hydrogen), exist during the melting.

- Nitrogen is present in the charge/feed materials.

- Nitrogen in the stirring gases (lance and bottom stirring).

- Nitrogen pick up from ladle addition such as carburizers and ferro-alloys,

- Nitrogen is absorbed from the atmosphere during the tapping of steel or excessive stirring.

The $[\mathrm{N}]$ pickup in steel melt is also related to the $[\mathrm{O}]_{\text {total }}$ increase and also lower steel cleanliness. ${ }^{15}$

The basic thermodynamics for the calculation of equilibrium nitrogen solubility (phase equilibria) in the steel melt at different steel-melt compositions are presented and discussed in this paper along with nitride non-metallic inclusion precipitation in the melt. Some practical examples of coarse cuboidal nitride inclusions and their effect on steel properties are also presented. Due to limited dissolution of coarse nitrides during solution annealing prior to hot rolling their formation must be limited.

\section{THERMODYNAMIC BACKGROUND}

The dissolution of nitrogen in molten steel is expressed in Equation (1): ${ }^{16}$

$$
\begin{gathered}
\frac{1}{2} \mathrm{~N}_{2(\mathrm{~g})}=[\mathrm{N}] \\
K_{\mathrm{N}}=\frac{[w / \% \mathrm{~N}] \cdot f_{\mathrm{N}}}{\sqrt{\left(p_{\mathrm{N}_{2}}\right)}}
\end{gathered}
$$

The nitrogen solubility in liquid $\mathrm{Fe}$ at the standard 1 atmosphere nitrogen pressure was determined by $\mathrm{H}$. Wada et al. ${ }^{17}$ as:

$$
\lg K_{\mathrm{N}}=\frac{430}{T}-1.125
$$

An example of the effect of partial $\mathrm{N}_{2}(\mathrm{~g})$ pressure and temperature on solubility in liquid $\mathrm{Fe}$ is shown in Table 1.

According to Table $\mathbf{1}$ it is obvious that different concepts of steelmaking practices (like vacuum degassing) can result in different values of nitrogen after degassing.

Table 1: Equilibrium dissolved nitrogen in $\mathrm{Fe}(1)$ at different $\mathrm{N}_{2}$ pressures (1 atm to $0.001 \mathrm{~atm})$ and temperatures (1723 $\mathrm{K}$ to $1973 \mathrm{~K}$ )

\begin{tabular}{|c|c|c|c|c|}
\hline & \multicolumn{4}{|c|}{$\mathrm{N}_{2}$ pressure (atm) } \\
\hline Temperature & 1 & 0.1 & 0.01 & 0.001 \\
\hline$K$ & \multicolumn{4}{|c|}{ Equilibrium dissolved $N(w / \%)$} \\
\hline 1973 & 0.0454 & 0.0144 & 0.0045 & 0.0014 \\
\hline 1923 & 0.0448 & 0.0142 & 0.0045 & 0.0014 \\
\hline 1873 & 0.0442 & 0.0140 & 0.0044 & 0.0014 \\
\hline 1823 & 0.0436 & 0.0138 & 0.0044 & 0.0014 \\
\hline 1773 & 0.0429 & 0.0136 & 0.0043 & 0.0014 \\
\hline 1723 & 0.0422 & 0.0133 & 0.0042 & 0.0013 \\
\hline
\end{tabular}

The solubility of nitrogen in liquid steel changes with the steel chemical composition. The constant in equation $\mathrm{K}_{\mathrm{N}}$ can be modified for a given steel composition and nitrogen partial pressure using Equation (4). While the influence of nitrogen pressure is rather straightforward, the influence of the chemical composition is calculated by using first-order interaction coefficients, as shown by Equation (5). The data for interaction coefficients is given in Table 2. The values of the interaction parameters can, however, vary. Zirconium and titanium are the elements that most strongly increase the nitrogen solubility; however, they regularly form nitrides and can cause non-metallic inclusion formation. In practice chromium is the most influential, due to its high alloying content in stainless steels. Some austenitic stainless steels like Nitronic 50 can have up to 0.4 w/\% nitrogen along with $23 w / \% \mathrm{Cr}$.

$$
\begin{gathered}
\lg [w / \% \mathrm{~N}]=\lg K_{\mathrm{N}}-\lg f_{\mathrm{N}}+\frac{1}{2} \lg p_{\mathrm{N}_{2}} \\
\lg f_{\mathrm{N}}=\sum e_{\mathrm{N}}^{x} \cdot[w / \% \mathrm{~N}]
\end{gathered}
$$


Table 2: Interaction coefficients $e_{y}^{x}$ in dilute liquid iron for selected elements at $1873 \mathrm{~K}^{18-23}$

\begin{tabular}{|c|c|c|c|c|c|c|c|c|}
\hline $\mathrm{Y} \backslash \mathrm{X}$ & $\mathrm{Al}$ & $\mathrm{B}$ & $\mathrm{C}$ & $\mathrm{Cr}$ & $\mathrm{H}$ & $\mathrm{Mn}$ & $\mathrm{Mo}$ & $\mathrm{N}$ \\
\hline $\mathrm{Al}$ & 0.045 & & 0.091 & & 0.24 & & & -0.058 \\
\hline $\mathrm{B}$ & & 0.038 & 0.22 & & 0.49 & & & 0.074 \\
\hline $\mathrm{N}$ & -0.028 & 0.094 & 0.13 & -0.047 & 0 & -0.02 & -0.011 & 0 \\
\hline $\mathrm{Nb}$ & & & -0.49 & & -0.61 & 0 & & -0.42 \\
\hline $\mathrm{Ti}$ & 0.0037 & & -0.165 & 0.055 & -1.1 & 0.0043 & & -1.8 \\
\hline $\mathrm{V}$ & & & -0.34 & & -0.59 & & & -0.35 \\
\hline $\mathrm{Zr}$ & & & & & & & & -4.1 \\
\hline & $\mathrm{Nb}$ & $\mathrm{Ni}$ & $\mathrm{O}$ & $\mathrm{S}$ & $\mathrm{Si}$ & $\mathrm{Ti}$ & $\mathrm{V}$ & $\mathrm{Zr}$ \\
\hline $\mathrm{Al}$ & & & -6.6 & 0.03 & 0.0056 & 0.004 & & \\
\hline $\mathrm{B}$ & & & -1.8 & 0.048 & 0.078 & & & \\
\hline $\mathrm{N}$ & -0.06 & 0.01 & 0.05 & 0.007 & 0.047 & -0.53 & -0.093 & -0.63 \\
\hline $\mathrm{Nb}$ & & & -0.83 & -0.047 & & & & \\
\hline $\mathrm{Ti}$ & & & -1.8 & -0.11 & 0.05 & 0.048 & & \\
\hline $\mathrm{V}$ & & & -0.97 & -0.028 & 0.042 & & 0.015 & \\
\hline $\mathrm{Zr}$ & & & -2.6 & -0.16 & & & & 0.02 \\
\hline
\end{tabular}

A graphical representation of the influence of some alloying elements on the nitrogen solubility is given in Figure 1. The rule of thumb is that the nitride-forming elements increase the solubility, while others like $\mathrm{Ni}$ and Si decrease it.

\section{NITROGEN IN STEEL}

Generally, while the steel is liquid the nitrogen is always present in the solution. However, the solubility of nitrogen in liquid steel is commonly a couple of times greater than in $\delta$-ferrite or $\gamma$-austenite, as seen in Figure 2. So, when considering the effect of nitrogen alloying its change in solubility during solidification must be considered.

Excessive nitrogen almost always impairs the steel's target functional or mechanical properties. Of course, this also depends on the steel's chemical composition, micro-alloying elements and the target values of carbon

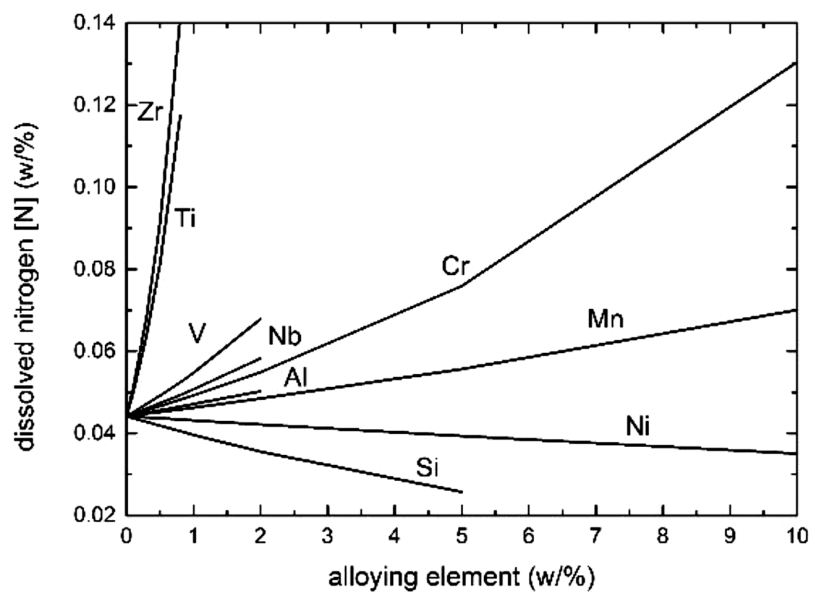

Figure 1: Calculated influence of alloying elements on nitrogen solubility using interaction coefficients given in Table 2, $p=1$ atm, $T=1873 \mathrm{~K}\left(1600^{\circ} \mathrm{C}\right)$

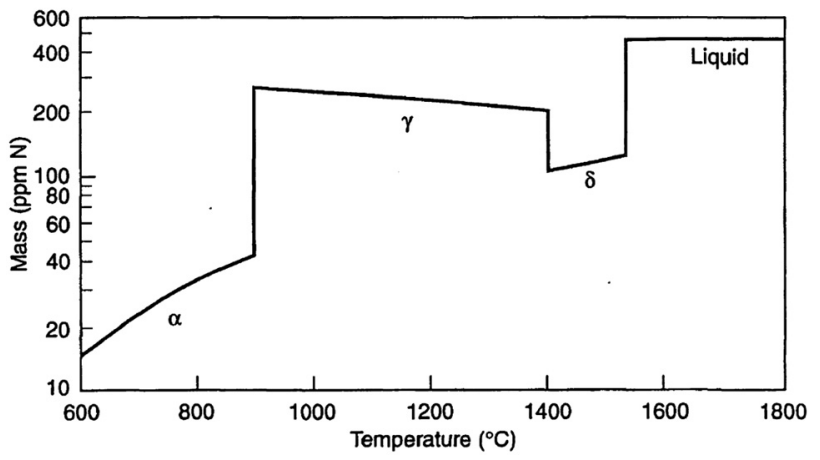

Figure 2: Solubility of nitrogen in pure iron (or low-alloy steels) at 1 atm pressure of $\mathrm{N}_{2}{ }^{24}$

and nitrogen. But generally, the solidification of steel can result in three nitrogen-related phenomena:

- formation of blowholes;

- solidification of steel with nitrogen in interstitial solid solution;

- precipitation of one or more nitride compounds.

\subsection{Blowholes}

Blowholes (porosity) are formed when the solubility of the gases dissolved in liquid steel is locally exceeded. In this case the thermodynamic driving force tends to reduce the dissolved gas content by forming gas bubbles. Gas-bubble formation occurs at the solidification front (solid/liquid interface) where the gaseous elements are rejected from the solid and concentrate in the liquid (in the same way that segregations occur). Blowholes and pinholes can not only effect the internal slab quality, but also cause surface defects. The primary gases contributing to blowhole formation in steel are $\mathrm{CO}, \mathrm{H}_{2}$ and $\mathrm{N}_{2}{ }^{25}$

$$
p\left(\mathrm{H}_{2}\right)+p\left(\mathrm{~N}_{2}\right)+p(\mathrm{CO})>p(\operatorname{atm})+p(\mathrm{Fe})+\frac{2 \sigma}{r}
$$

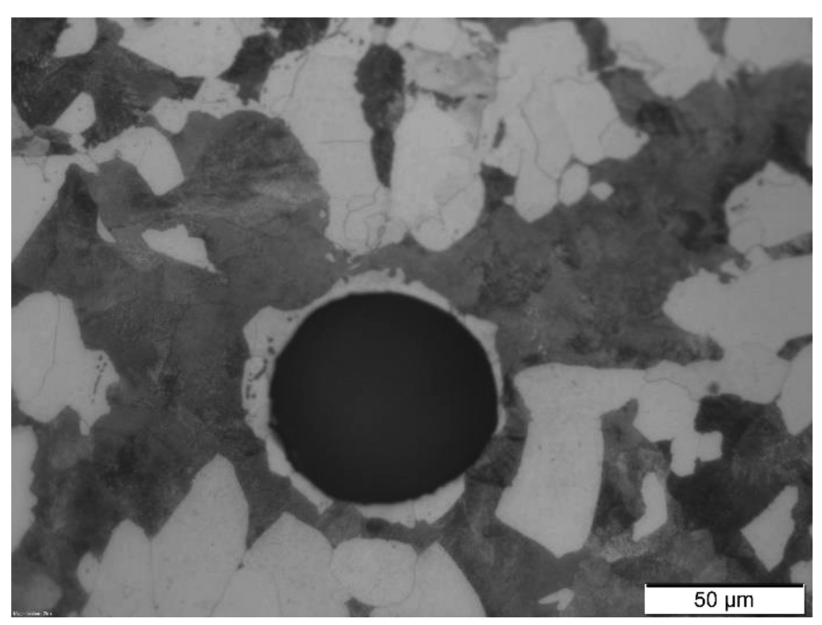

Figure 3: Example of a small gas bubble in a continuously cast billet (30MnVS6), as-cast condition, etched with nital $4 \%$ 
where $p(\mathrm{~atm})$ is the atmospheric surface pressure on the liquid in the mould, $\mathrm{p}(\mathrm{Fe})$ is the ferro-static pressure at the location of the blowhole, and is expressed as:

$$
p(\mathrm{Fe})=\rho_{\mathrm{Fe}} \cdot \mathrm{g} \cdot h,
$$

(the density of liquid iron $\rho_{\mathrm{Fe}}=7 \mathrm{~g} / \mathrm{cm}^{3},{ }^{26} \mathrm{~g}=9.81 \mathrm{~m} / \mathrm{s}^{2}$, $h$ is the height in meters).

$\sigma$ is the surface tension of the liquid steel in contact with the gas bubble of radius $r$. The surface tension of liquid iron at $1873 \mathrm{~K}$ is $1890 \mathrm{mN} / \mathrm{m}^{27}$.

Pinholes and blowholes form when the following conditions are met:

$$
p\left(\mathrm{H}_{2}\right)+p\left(\mathrm{~N}_{2}\right)+p(\mathrm{CO})>1.5 \operatorname{atm}^{25}
$$

In such cases, proper vacuum degassing or the addition of nitride-forming elements can prevent the formation of a defect like that shown in Figure 3 .

\subsection{Solid solution}

The effect of nitrogen on the mechanical properties is the result of interstitial solid-solution strengthening by the free nitrogen. A high nitrogen content may result in inconsistent mechanical properties in hot-rolled products, embrittlement of the heat-affected zone (HAZ) of welded steels, and poor cold formability. Interstitial solid-solution nitrogen can result in strain ageing that is caused by the interaction of the interstitial atoms and the elastic stresses related to the presence of dislocations. ${ }^{28}$ High nitrogen in vanadium-based micro-alloyed steels was considered to cause unsatisfactory HAZ by solute nitrogen toughness degradation. But R. Lagneborg et al. ${ }^{29}$ showed that this is not true because the HAZ toughness strongly depends on the welding parameters, mainly the heat input.

\section{NITRIDES}

In most steel compositions nitrides do not form in the liquid steel if the solubility products are taken into

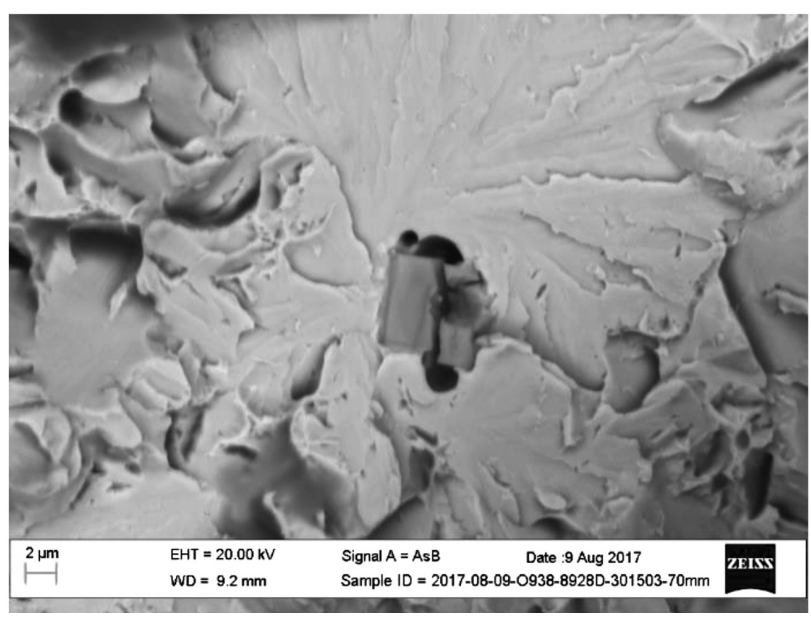

Figure 4: Quasi-cleavage brittle fracture caused by the presence of coarse nitrides $(0.14 w / \% \mathrm{C}, 0.02 w / \% \mathrm{Nb}, 0.0058 w / \% \mathrm{~N})$ account. With proper steelmaking and casting practices these compounds most often precipitate during the cooling of the solidified steel along the austenite grain boundaries. These precipitates influence the mechanical properties of the steel both at room temperature and hot working temperatures. Nitride precipitates can have a beneficial effect on the steel properties, from grain refining to precipitation hardening. However, when nitrides are formed in the melt or during solidification they may be considered as non-metallic inclusions and do not have the same beneficial effects. Typically, Al, $\mathrm{Nb}, \mathrm{Ti}, \mathrm{V}, \mathrm{Zr}$ and also B form nitride inclusions in steel. ${ }^{30}$ Nitrides are known to inhibit grain growth, if the critical grain radius has not been reached, be it during high-temperature annealing, slab soaking, or during welding in the heat-affected zone. ${ }^{31,32}$ Nitrides can also control the grain size evolution during hot working (rolling, forging). Nevertheless, micro-alloying additions that interact with nitrogen have a direct influence on the recrystallization behaviour. The thermodynamic conditions for the formation of such coarse nitride inclusions are described and examples from experiments and industrial practice are shown. The coarse nitrides cause the loss of the austenite grain-boundary pinning effect that is provided by the micro-alloying elements during hot deformation (rolling, forging).

In some cases of alloyed steels, nitrides can precipitate in the liquid steel (above liquidus temperature, $T_{\text {liq }}$ ) or during solidification (between liquidus and solidus, $T_{\text {sol }}$ temperature of particular steel grade). These coarse nitrides usually have a detrimental effect on the steel properties and are considered as non-metallic inclusions. The promotion of a quasi-cleavage brittle fracture and decreased impact toughness can occur due to coarse nitride non-metallic inclusions, as shown by an example of a titanium nitride (TiN) in Figure 4.

In the case of coarse niobium carbonitrides a drastic decrease of deformation properties perpendicular to the

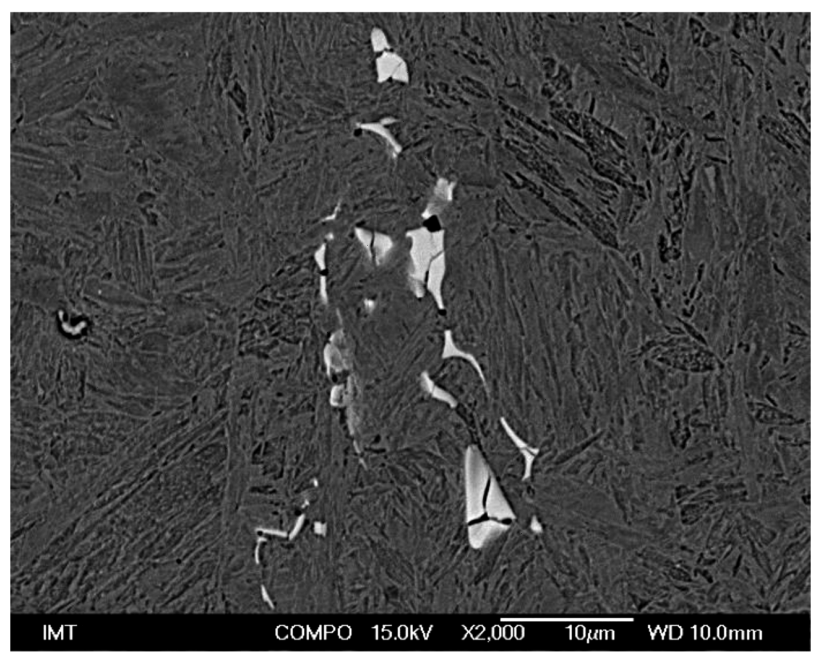

Figure 5: Coarse carbonitride cracking during hot working $(0.17 \mathrm{w} / \%$ $\mathrm{C}, 0.43 w / \% \mathrm{Nb}, 0.060 w / \% \mathrm{~N})$ 


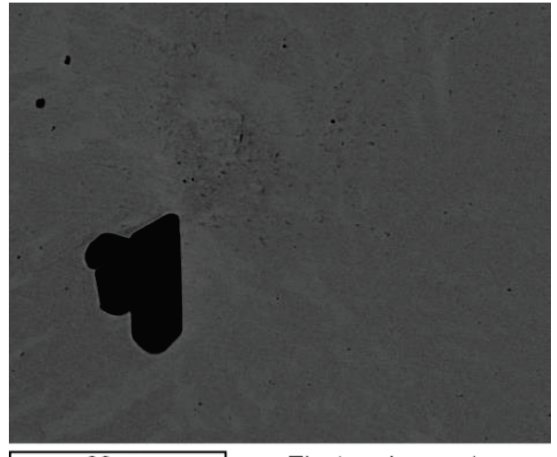

$20 \mu \mathrm{m}$

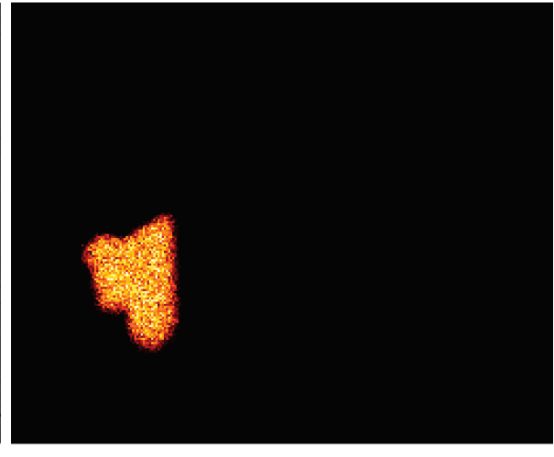

Al Ka1

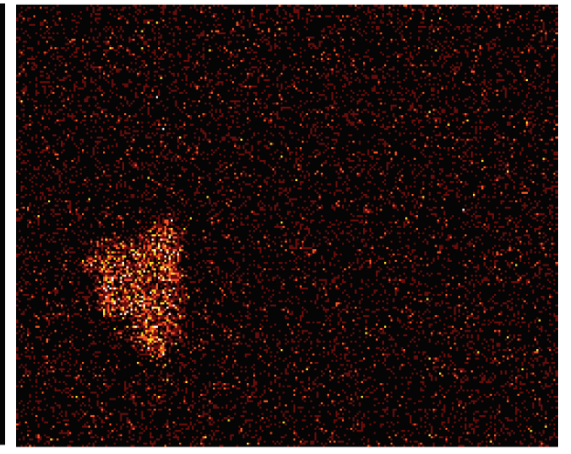

NKa1 2

Figure 6: Mapping of a coarse AlN non-metallic inclusion ( 1 w/\% Al, $0.008 w / \% \mathrm{~N})$

surface of the hot rolled products is expected, tested in accordance with the standard SIST EN 10164:2018. ${ }^{33}$

The reaction equilibrium for the formation of metal nitride in liquid iron can be written as:

$$
(\mathrm{MN})=[\mathrm{M}]+[\mathrm{N}]
$$

where $\mathrm{M}$ represents a nitride forming metal.

The values of the Gibbs free energies for nitride formation in Equations (11, 13, 15, 17 and 19) were taken from HSC Chemistry 8.0.1 and data from Sigworth and Elliot was used for the transformation from mole to weight percent with the infinitely dilute iron solution. ${ }^{34}$

\subsection{Aluminium nitrides}

Usually, aluminium nitrides (AIN) secondary phase particles precipitate on the grain boundaries as fine particles in Al killed steels. These precipitates supress grain growth during heat treatment. ${ }^{35-37}$ However, AlN as inclusions occurs in high-Al steel. In the case of other micro-alloying elements the solubility product of AIN is drastically influenced. The AlN inclusions can precipitate due to the enrichment of the solute in liquid phase during solidification and induce intergranular fracture. ${ }^{38}$

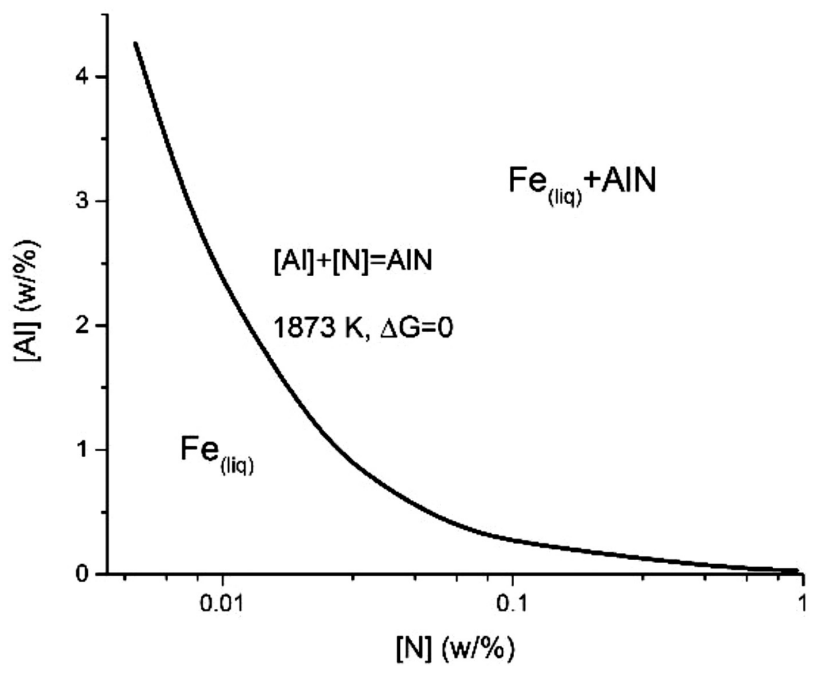

Figure 7: AlN equilibrium precipitation in $\mathrm{Fe}(1)$ at $1873 \mathrm{~K}$ for different $\mathrm{Al} / \mathrm{N}$ concentrations
Hard AlN inclusions are also crack-initiation sites and can decrease hot ductility. ${ }^{39,40}$ Figure 6 shows an example of an aluminium nitride inclusion from an industrial sample of NAK80 age-hardening plastic mould steel. In this particular case the aluminium nitrides proved to be problematic during the finish polishing of the mould. Tools for plastic moulding require a high surface finish, especially for transparent or high-gloss products. The concentrations of aluminium and nitrogen needed for AlN inclusion formation at $1873 \mathrm{~K}\left(1600{ }^{\circ} \mathrm{C}\right)$ calculated using Equation (11) are shown in Figure 7.

$$
\begin{gathered}
{[\mathrm{Al}]+[\mathrm{N}]=\mathrm{AlN}} \\
\Delta \mathrm{G}^{0}=-269269.96 \mathrm{~J}+121.2 \mathrm{~J} / \mathrm{K} \cdot 1873 \mathrm{~K}
\end{gathered}
$$

\subsection{Boron nitride}

Soluble boron is normally used to improve the steel hardenability, which is directly related to the mechanical properties achieved in the final state. However, BN precipitates or inclusions do not contribute to the steel hardenability and do not have a significant role in the martensitic transformation, in fact $\mathrm{BN}$ are usually considered as boron loss. Interestingly, $\mathrm{BN}$ inclusions have been known to improve machinability; they have been

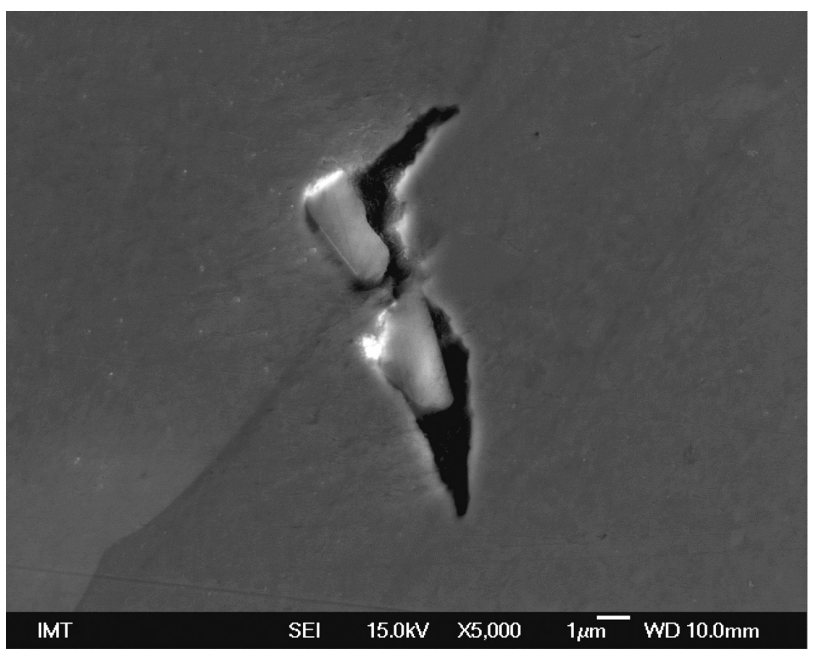

Figure 8: BN nucleated on an alumina inclusion $(0.1 w / \%$ B, $0.02 w / \%$ N) 


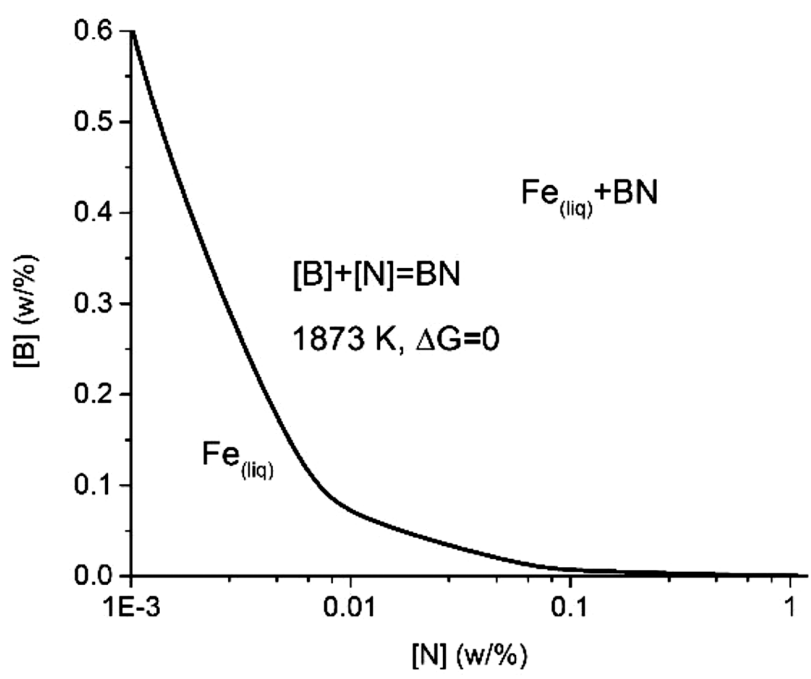

Figure 9: BN equilibrium precipitation in $\mathrm{Fe}(1)$ at $1873 \mathrm{~K}$ for different $\mathrm{B} / \mathrm{N}$ concentrations

successfully used in the development of free machining stainless steels. BN inclusions can form during the steel solidification process or as secondary phases, they are usually small, so unlike $\mathrm{MnS}$, they do not worsen the mechanical properties of steel. ${ }^{41-47}$ Figure 8 shows an example of a boron nitride inclusion from an experimental laboratory steel sample with $0.1 \mathrm{w} / \% \mathrm{~B}$ and 0.02 $w / \% \mathrm{~N}$. The concentrations of boron and nitrogen needed for $\mathrm{BN}$ inclusion formation at $1873 \mathrm{~K}\left(1600{ }^{\circ} \mathrm{C}\right)$ calculated using Equation (13) are shown in Figure 9.

$$
\begin{gathered}
{[\mathrm{B}]+[\mathrm{N}]=\mathrm{BN}} \\
\Delta \mathrm{G}^{0}=-190093.5 \mathrm{~J}+84.0 \mathrm{~J} / \mathrm{K} \cdot 1873 \mathrm{~K}
\end{gathered}
$$

\subsection{Niobium nitrides}

Niobium can be, like titanium, used to stabilise stainless steels. ${ }^{48,49}$ Niobium has a smaller tendency to form large detrimental nitrides than titanium. In fact, niobium is more prone to form carbides. Niobium carbo-nitride

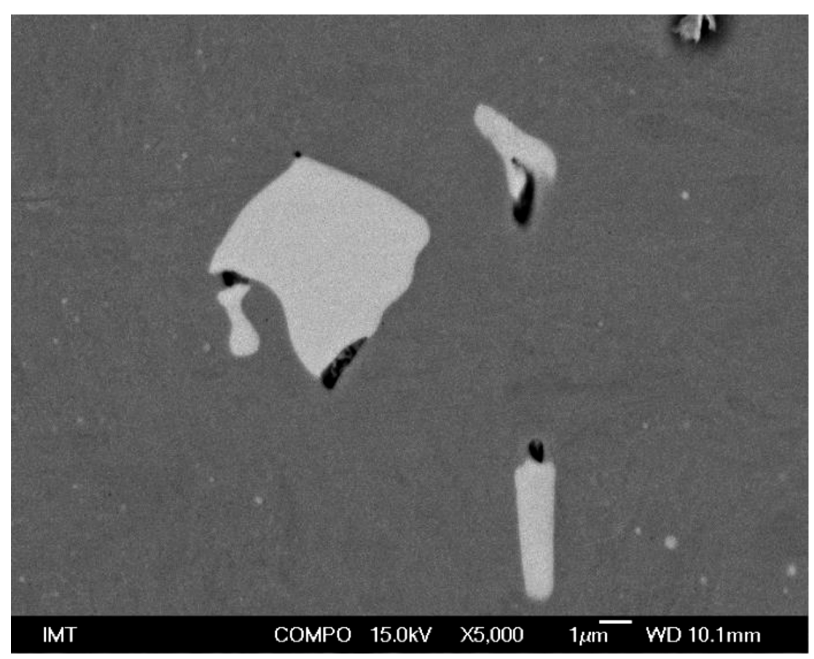

Figure 10: Coarse niobium nitrides $(0.2 w / \% \mathrm{C}, 0.5 w / \% \mathrm{Nb}, 0.075$ $w / \% \mathrm{~N})$ precipitates are known to decrease hot ductility. ${ }_{40,50,51}$ Niobium nitrides and carbo-nitrides delay the onset of dynamic recrystallization during hot working, inhibit austenite grain growth during high-temperature annealing and therefore play an important role in grain refinement. ${ }^{37,52}$ Figure $\mathbf{1 0}$ shows an example of a niobium nitride inclusion from an industrial sample of X19CrMoNbVN11-1 creep-resistant steel. The sample in Figure 10 was taken after hot forging; void formation is visible at the nitride corners along the direction of material flow. The concentrations of niobium and nitrogen needed for $\mathrm{NbN}$ inclusion formation at $1873 \mathrm{~K}$ $\left(1600{ }^{\circ} \mathrm{C}\right)$ calculated using Equation (5) are shown in Figure 11.

$$
\begin{gathered}
{[\mathrm{Nb}]+[\mathrm{N}]=\mathrm{NbN}} \\
\Delta \mathrm{G}^{0}=-221557.9 \mathrm{~J}+102.1 \mathrm{~J} / \mathrm{K} \cdot 1873 \mathrm{~K}
\end{gathered}
$$

\subsection{Titanium nitrides}

Titanium is often added to steels for grain size control. This is an important role in HSLA (high strength low alloy) steels, where it also effects the critical deformation needed for the dynamic recrystallization during hot rolling. Some special applications include the stabilization of stainless steels, where it prevents the formation of chromium carbides and intergranular corrosion. ${ }^{48,49}$ On the other hand, titanium nitrides can promote local corrosion in stainless steels. ${ }^{49,53} \mathrm{TiN}$ formation in ferritic stainless steels refines the microstructure as it promotes the heterogeneous nucleation of delta ferrite. ${ }^{23,54}$ The addition of titanium can also prevent $\mathrm{BN}$ formation to improve the effect of boron on steel hardenability for HSLA and similar grade steels. ${ }^{55}$ The formation of solid TiN inclusions in the melt can also lead to nozzle clogging or even "floater formation" during continuous casting. ${ }^{56,57}$ The TiN particles themselves preferably nucleate on $\mathrm{Mg}$-Al oxides, where the $\mathrm{Mg}$ content increases the TiN nucleation potential. ${ }^{54,57-59}$

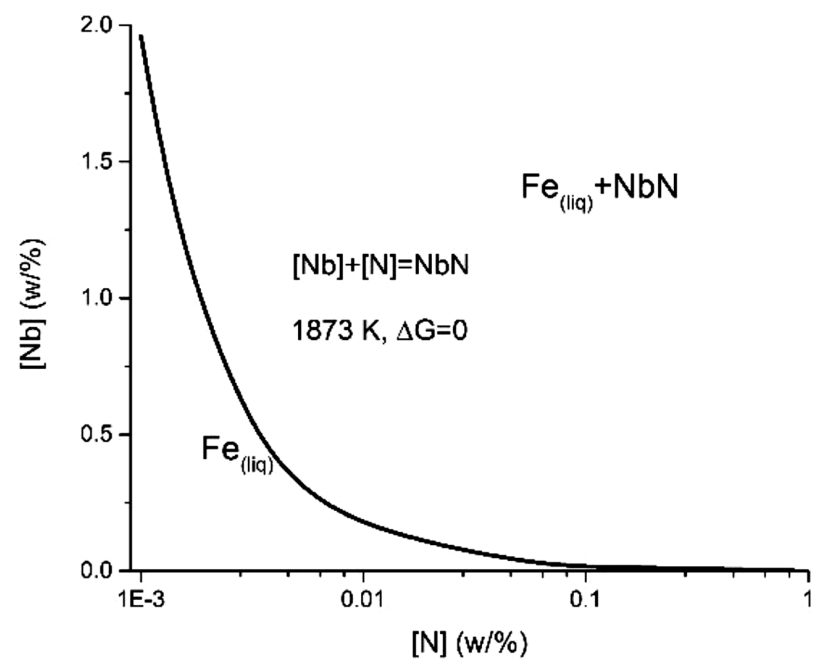

Figure 11: $\mathrm{NbN}$ equilibrium precipitation in $\mathrm{Fe}(1)$ at $1873 \mathrm{~K}$ for different $\mathrm{Nb} / \mathrm{N}$ concentrations 


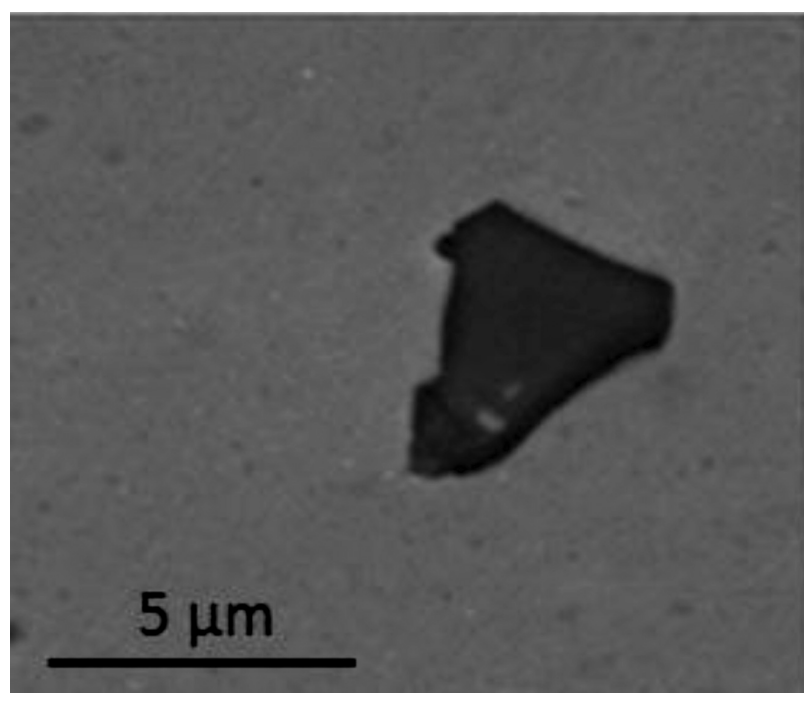

Figure 12: Coarse titanium nitrides $(0.38 w / \% \mathrm{C}, 0.005 w / \% \mathrm{Ti}, 0.007$ $w / \% \mathrm{~N})$

These inclusions can decrease ductility and cause crack initiation and propagation; their sharp edges are especially harmful for stress concentrating. ${ }^{2}$ Figure 12 shows an example of a titanium nitride inclusion from an industrial sample of $\mathrm{H} 13$ hot-work tool steel. The concentrations of titanium and nitrogen needed for TiN inclusion formation at $1873 \mathrm{~K}\left(1600{ }^{\circ} \mathrm{C}\right)$ calculated using Equation (17) are shown in Figure 13.

$$
\begin{gathered}
{[\mathrm{Ti}]+[\mathrm{N}]=\mathrm{TiN}} \\
\Delta \mathrm{G}^{0}=-293703.2 \mathrm{~J}+106.4 \mathrm{~J} / \mathrm{K} \cdot 1873 \mathrm{~K}
\end{gathered}
$$

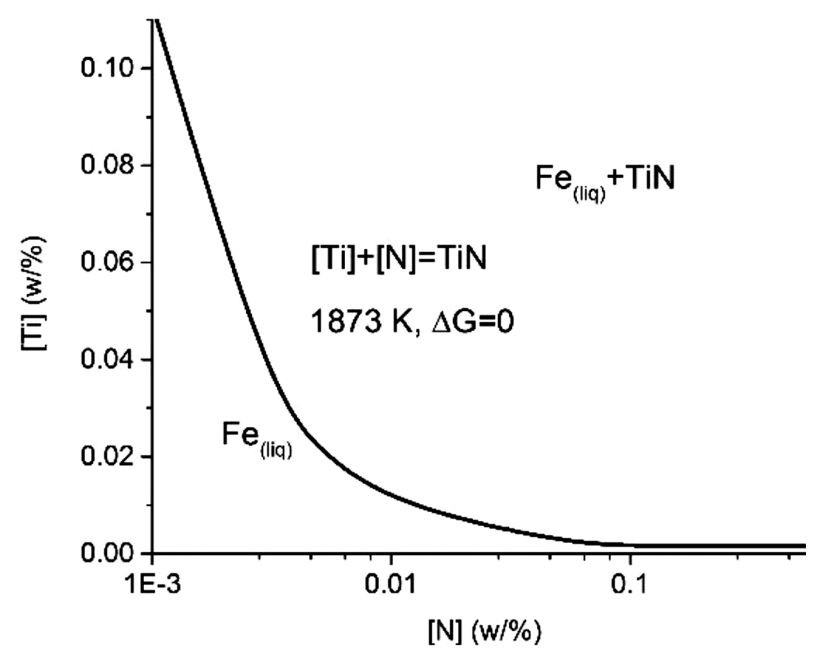

Figure 13: TiN equilibrium precipitation in $\mathrm{Fe}(1)$ at $1873 \mathrm{~K}$ for different $\mathrm{Ti} / \mathrm{N}$ concentrations

\subsection{Zirconium nitrides}

In the steel melt zirconium has a high affinity to both oxygen and nitrogen. ${ }^{10,60,61}$ In a fully de-oxidized steel, zirconium combines with nitrogen in preference to sulphur or carbon and forms $\mathrm{ZrN}$ nitrides. ${ }^{62}$ Because $\mathrm{ZrN}$ are already present in the melt they can also serve as nucleation sites for $\mathrm{MnS} .{ }^{61}$ The addition of $\mathrm{Zr}$ through the formation of $\mathrm{ZrN}$ can have a significant effect on the increased ductility and toughness by refining the austenite grain size. ${ }^{62}$ Figure $\mathbf{1 4}$ shows an example of a zirconium nitride inclusion from an experimental labo-
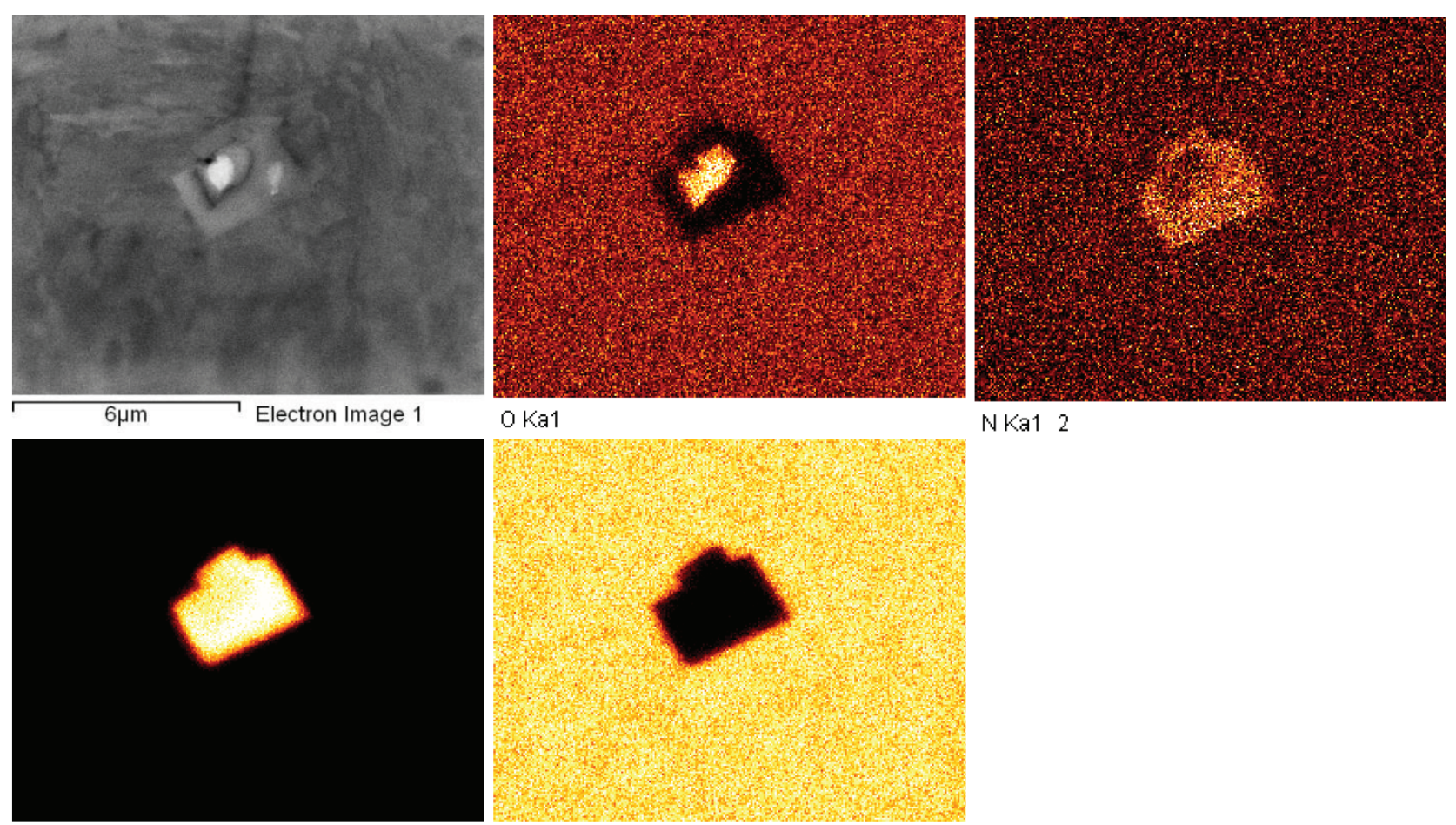

$\mathrm{O} \nless \mathrm{a} 1$

NKa1 2

Zr La1

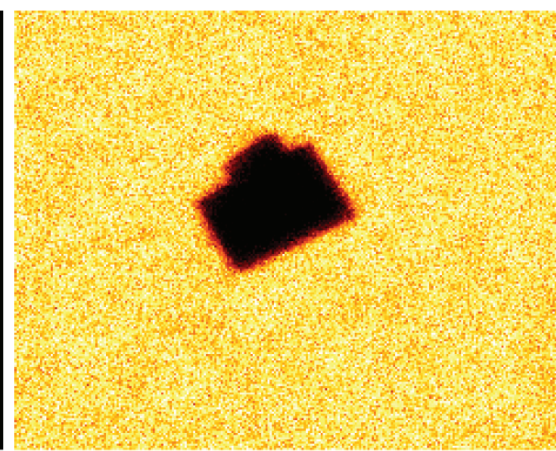

Fe Ka1

Figure 14: Coarse zirconium nitride with a zirconium oxide nucleus $(0.11 w / \% \mathrm{C}, 0.015 w / \% \mathrm{Zr}$ and $0.01 w / \% \mathrm{~N})$ 


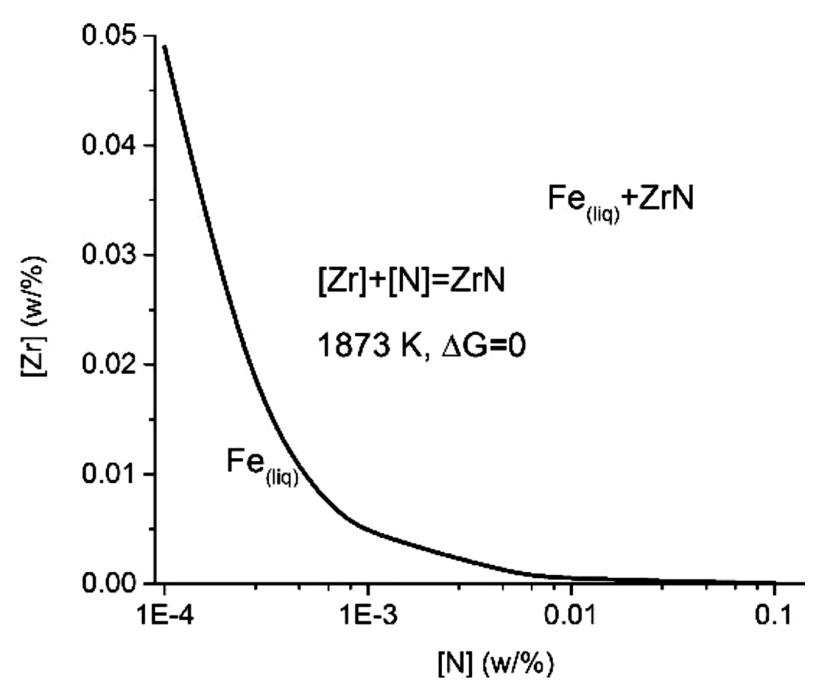

Figure 15: $\mathrm{ZrN}$ equilibrium precipitation in $\mathrm{Fe}(1)$ at $1873 \mathrm{~K}$ for different $\mathrm{Zr} / \mathrm{N}$ concentrations

ratory steel sample. The nitride nucleated on a zirconium oxide inclusion. The concentrations of zirconium and nitrogen needed for $\mathrm{ZrN}$ inclusion formation at $1873 \mathrm{~K}$ $\left(1600{ }^{\circ} \mathrm{C}\right)$ calculated using Equation (17) are shown in Figure 15.

$$
\begin{gathered}
{[\mathrm{Zr}]+[\mathrm{N}]=\mathrm{ZrN}} \\
\Delta \mathrm{G}^{0}=-312121.2 \mathrm{~J}+116.8 \mathrm{~J} / \mathrm{K} \cdot 1873 \mathrm{~K}
\end{gathered}
$$

\section{CONCLUSIONS}

Generally speaking, nitrogen represents an impurity in steel, but when strong nitride-forming elements are alloyed to the steel in small amounts (micro-alloying) it takes on an important role.

Non-metallic inclusions obviously have a negative effect on mechanical properties, especially on ductility (toughness, formability). This is also the case with coarse nitrides that form in the steel melt. Coarse nitrides are even more problematic, because they deplete the matrix of micro-alloying elements. This negatively effects the formation of fine nitride precipitates that positively contribute to target strength and toughness. Both properties are strongly related to grain size: the finer the grains the higher the strength and toughness. The effect of fine nitride precipitation can be utilised to achieve a fine-grained microstructure in products during hot working and/or final heat treatment.

The titanium nitride is the most representative nitride non-metallic inclusion, as it is most commonly found in steels. The nitride non-metallic inclusions also have a negative effect on the steel properties, because of their relatively large size (above $5 \mu \mathrm{m}$ ) and sharp-edged shape. They act as stress risers. This is why it is crucial that the excessive precipitation of coarse nitrides in the steel melt should be prevented or minimized.

Thermodynamic calculations can help us both predict the conditions for nitride formation as well as the equi- librium solubility of nitrogen under different nitrogen gas partial pressures, temperatures and melt compositions.

\section{Acknowledgements}

This research was made as a part of ČMRLJ research project co-financed by the Republic of Slovenia and the European Union under the European Regional Development Fund.

\section{REFERENCES}

${ }^{1}$ L. Zhang, B. G. Thomas, State of the art in the control of inclusions during steel ingot casting, Metall. Mater. Trans. B Process Metall. Mater. Process. Sci., 37 (2006) 733-761, doi:10.1007/s11663006-0057-0

${ }^{2}$ C. Gu, J. Lian, Y. Bao, W. Xiao, S. Münstermann, Numerical study of the effect of inclusions on the residual stress distribution in high-strength martensitic steels during cooling, Appl. Sci., 9 (2019), doi:10.3390/app9030455

${ }^{3}$ D. Spriestersbach, P. Grad, E. Kerscher, Influence of different non-metallic inclusion types on the crack initiation in high-strength steels in the VHCF regime, Int. J. Fatigue, 64 (2014) 114-120, doi:10.1016/j.ijfatigue.2014.03.003

${ }^{4}$ B. Zorc, M. Imamović, L. Kosec, B. Kosec, A. Nagode, Influence of non-metallic inclusions on the formation of hot cracks in the weld and heat-affected zone, Mater. Tehnol., 48 (2014) 149-154

${ }^{5}$ K. I. Yamamoto, H. Yamamura, Y. Suwa, Behavior of non-metallic inclusions in steel during hot deformation and the effects of deformed inclusions on local ductility, ISIJ Int., 51 (2011) 1987-1994, doi:10.2355/isijinternational.51.1987

${ }^{6}$ R. Arreola-Herrera, A. Cruz-Ramírez, J. E. Rivera-Salinas, J. A. Romero-Serrano, R. G. Sánchez-Alvarado, The effect of nonmetallic inclusions on the mechanical properties of $32 \mathrm{CDV} 13$ steel and their mechanical stress analysis by numerical simulation, Theor. Appl. Fract. Mech., 94 (2018) 134-146, doi:10.1016/j.tafmec. 2018.01.013

${ }^{7}$ A. L. V. Da Costa, E. Silva, The effects of non-metallic inclusions on properties relevant to the performance of steel in structural and mechanical applications, J. Mater. Res. Technol., 8 (2019) 2408-2422, doi:10.1016/j.jmrt.2019.01.009

${ }^{8}$ J. H. Shin, J. H. Park, Formation Mechanism of Oxide-Sulfide Complex Inclusions in High-Sulfur-Containing Steel Melts, Metall. Mater. Trans. B Process Metall. Mater. Process. Sci., 49 (2018) 311-324, doi:10.1007/s11663-017-1152-0

${ }^{9}$ B. Šuler, J. Burja, J. Medved, Modification of non-metallic inclusions with rare-earth metals in 50CrMov13-1 steel, Mater. Tehnol., 53 (2019) 441-447, doi:10.17222/mit.2018.271

${ }^{10}$ M. Koležnik, J. Burja, B. Šetina Batič, A. Nagode, J. Medved, De-oxidation of Pk942 steel with Ti and Zr, Mater. Tehnol., 51 (2017) 1031-1036, doi:10.17222/mit.2017.082

${ }^{11}$ L. Krajnc, P. Mrvar, J. Medved, Thermodynamic characterization of multiphase non-metallic inclusions in re-sulphurised steel grades, Mater. Tehnol., 48 (2014) 923-929

${ }^{12}$ L. Krajnc, G. Klančnik, P. Mrvar, J. Medved, Thermodynamic analysis of the formation of non-metallic inclusions during the production of c45 steel, Mater. Tehnol., 46 (2012) 361-368

${ }^{13}$ A. L. V. Da Costa E Silva, Non-metallic inclusions in steels - Origin and control, J. Mater. Res. Technol., 7 (2018) 283-299, doi:10.1016/ j.jmrt.2018.04.003

${ }^{14}$ ASTM E45-18a, Standard Test Methods for Determining the Inclusion Content of Steel, ASTM International, West Conshohocken, PA, 2018, www.astm.org, doi:10.1520/E0045-18A 
${ }^{15}$ L. Zhang, B.G. Thomas, X. Wang, K. Cai, Evaluation and control of steel cleanliness - Review, Steelmak. Conf. Proc., 2002, 431-452

${ }^{16}$ J. H. Shin, L. Joonho, D. J. Min, J. Park, Solubility of Nitrogen in High Manganese Steel (HMnS) Melts: Interaction Parameter between Mn and N, Metall. Mater. Trans. B Process Metall. Mater. Process. Sci., 42 (2011) 5, doi:10.1007/s11663-011-9582-6

${ }^{17}$ H. Wada, S. W. Lee, R. D. Pehlke, Nitrogen solubility in liquid Fe and Fe-Mn alloys, Metall. Trans. B., 17 (1986) 238-239, doi:10.1007/BF02670840

${ }^{18}$ H. Ono, Ã. K. Nakajima, S. Agawa, T. Ibuta, R. Maruo, T. Usui, Formation Conditions of $\mathrm{Ti} 2 \mathrm{O} 3, \mathrm{MgTi} 2 \mathrm{O} 4, \mathrm{Mg} 2 \mathrm{TiO} 4$, and MgAl $2 \mathrm{O} 4$ in $\mathrm{Ti}-\mathrm{Mg}$ - Al Complex Deoxidation of Molten Iron, Steel Res. Int., 86 (2015) 241-251, doi:10.1002/srin.201400034

${ }^{19}$ H. Yang, J. Ye, X. Wu, Y. Peng, Y. Fang, X. Zhao, Optimum Composition of CaO-SiO2-A12O3-MgO Slag for Spring Steel Deoxidized by Si and Mn in Production, Metall. Mater. Trans. B Process Metall. Mater. Process. Sci., 47 (2016) 1435-1444, doi:10.1007/s11663015-0581-X

${ }^{20}$ A. Karasev, H. Suito, Quantitative evaluation of inclusion in deoxidation of Fe-10 mass pct Ni alloy with Si, Ti, Al, Zr, and Ce, Metall. Mater. Trans. B Process Metall. Mater. Process. Sci., 30 (1999) 249-257, doi:10.1007/s11663-999-0054-1

${ }^{21}$ G. K. Sigworth, J. F. Elliott, The Thermodynamics of Liquid Dilute Iron Alloys, Met. Sci., 8 (1974) 298-310, doi:10.1179/msc. 1974.8.1.298

${ }^{22}$ W. Kim, J. Jo, T. Chung, D. Kim, J. Pak, Thermodynamics of Titanium, Nitrogen and TiN Formation in Liquid Iron, 47 (2007) 1082-1089

${ }^{23}$ J.-J. Pak, Y.-S. Jeong, I.-K. Hong, W.-Y. Cha, D.-S. Kim, Y.-Y. Lee, Thermodynamics of TiN Formation in Fe-Cr Melts, ISIJ Int., 45 (2005) 1106-1111, doi:10.2355/isijinternational.45.1106

${ }^{24}$ E. T. Turkdogan, Fundamentals of steelmaking, 1st ed., Maney Publishing, London, 2010, doi:10.1179/095066096790151213

${ }^{25}$ K. Huang, Q. Liu, Blowhole formation during solidification of liquid steel, Steel Res., 67 (1996) 268-272

${ }^{26}$ I. Jimbo, A.W. Cramb, The density of liquid iron-carbon alloys, Metall. Trans. B., 24 (1993) 5-10, doi:10.1007/BF02657866

${ }^{27}$ A. Kasama, A. McLean, W.A. Miller, Z. Morita, M.J. Ward, Surface tension of liquid iron and iron-oxygen alloys, Can. Metall. Q., 22 (1983) 9-17, doi:10.1179/cmq.1983.22.1.9

${ }^{28} \mathrm{~F}$. Vodopivec, Strain ageing of structural steels, Metalurgija, 43 (2004) 143-148

${ }^{29}$ R. Lagneborg, T. Siwecki, S. Zajac, B. Hutchinson, Role of vanadium in microalloyed steels, Scand. J. Metall., 28 (1999) 186-241

${ }^{30}$ P. V. Bizyukov, S. R. Giese, Effects of Zr, Ti, and Al Additions on Nonmetallic Inclusions and Impact Toughness of Cast Low-Alloy Steel, J. Mater. Eng. Perform., 26 (2017) 1878-1889, doi:10.1007/ s11665-017-2583-0

${ }^{31}$ N. Fujiyama, T. Nishibata, A. Seki, H. Hirata, K. Ogawa, Austenite grain growth simulation considering the solute-drag effect and pinning effect, Sci. Technol. Adv. Mater., 18 (2017) 1-8, doi:10.1080/14686996.2016.1244473

${ }^{32}$ T. N. Baker, Microalloyed steels, Ironmak. Steelmak., 43 (2016) 264-307, doi:10.1179/1743281215Y.0000000063

${ }^{33}$ EN 10164:2018, Steel products with improved deformation properties perpendicular to the surface of the product -Technical delivery conditions, ICS: 77.140.01, https://www.en-standard.eu/bs-en10164-2018-steel-products-with-improved-deformation-properties-p erpendicular-to-the-surface-of-the-product-technical-delivery-conditi ons/

${ }^{34}$ G. K. Sigworth, J. F. Elliot, The Thermodynamics of Liquid Dilute Iron Alloys, Met. Sci. B, (1974) 298-310

${ }^{35}$ F. Hoffmann, J. Kleff, R. Strunk, B. Clausen, Influence of process chains on heat treatment, Materwiss. und Werksttech, 49 (2018) 792-802, doi:10.1002/mawe.201700061

${ }^{36}$ B. Jiang, M. Wu, H. Sun, Z. Wang, Z. Zhao, Y. Liu, Prediction model of austenite growth and the role of $\mathrm{MnS}$ inclusions in non-quenched and tempered steel, Met. Mater. Int. 24 (2018) 15-22, doi:10.1007/s12540-017-7012-2

${ }^{37}$ S. Gündüz, M. A. Erden, H. Karabulut, M. Türkmen, Effect of the addition of niobium and aluminium on the microstructures and mechanical properties of micro-alloyed pm steels, Mater. Tehnol., 50 (2016) 641-648, doi:10.17222/mit.2015.248,

${ }^{38}$ N. H. Croft, A. R. Entwisle, G. J. Davies, Origins of dendritic AIN precipitates in aluminium-killed-steel castings, Met. Technol., 10 (2013) 125-129, doi:10.1179/030716983803291596

${ }^{39}$ J. H. Park, Y. Kang, Inclusions in Stainless Steels - A Review, Steel Res. Int. 88 (2017) 1-26. doi:10.1002/srin.201700130

${ }^{40}$ P. Sricharoenchai, C. Nagasaki, J. Kihara, Hot Ductility of High Purity Steels Containing Niobium, ISIJ Int., 32 (1992) 1102-1109

${ }^{41}$ Y. N. Wang, Y. P. Bao, M. Wang, L. C. Zhang, Y. N. Chen, Basic research on precipitation and control of $\mathrm{BN}$ inclusions in steel, Metall. Mater. Trans. B Process Metall. Mater. Process. Sci., 44 (2013) 1144-1154, doi:10.1007/s11663-013-9881-1

${ }^{42}$ S. Emura, M. Kawajiri, X. Min, S. Yamamoto, K. Sakuraya, K. Tsuzaki, Machinability Improvement and Its Mechanism in SUS304 Austenitic Stainless Steel by h-BN Addition, Tetsu-to-Hagane., 98 (2012) 358-367, doi:10.2355/tetsutohagane.98.358

${ }^{43}$ Y. Chen, Y. Bao, M. Wang, X. Cai, L. Wang, L. Zhao, Precipitation and Growth Behaviors of BN Inclusions in Molten Steel, ISIJ Int., 54 (2014) 2215-2220, doi:10.2355/isijinternational.54.2215

${ }^{44}$ Y. N. Wang, J. Yang, Y. P. Bao, Characteristics of BN Precipitation and Growth During Solidification of BN Free-Machining Steel, Metall. Mater. Trans. B Process Metall. Mater. Process. Sci., 45 (2014) 2269-2278, doi:10.1007/s11663-014-0146-4

${ }^{45}$ Y. N. Wang, Y. P. Bao, M. Wang, L. C. Zhang, Precipitation behavior of BN type inclusions in 42CrMo steel, Int. J. Miner. Metall. Mater, 20 (2013) 28-36, doi:10.1007/s12613-013-0689-4

${ }^{46}$ Y. N. Wang, Y. P. Bao, M. Wang, L. C. Zhang, Precipitation and control of BN inclusions in 42CrMo steel and their effect on machinability, Int. J. Miner. Metall. Mater., 20 (2013) 842-849, doi:10.1007/s12613-013-0805-5

${ }^{47}$ Y. nan Chen, Y. ping Bao, M. Wang, X. feng Cai, L. jing Wang, L. hua Zhao, Superior machinability of steel enhanced with BN and MnS particles, Int. J. Miner. Metall. Mater, 23 (2016) 276-282, doi:10.1007/s12613-016-1236-X

${ }^{48}$ M. Li, W. Zhang, X. Wang, E. Chen, C. Chen, H. Zhang, Effect of $\mathrm{Nb}$ on the Performance of 409 Stainless Steel for Automotive Exhaust Systems, Steel Research International, 89 (2018) 1-8, doi:10.1002/srin.201700558

${ }^{49}$ S. M. Gateman, L. I. Stephens, S. C. Perry, R. Lacasse, R. Schulz, J. Mauzeroll, The role of titanium in the initiation of localized corrosion of stainless steel 444, Npj Mater. Degrad., (2018) 1-8, doi:10.1038/s41529-018-0026-5

${ }^{50}$ L. Yang, Y. Li, Z. Xue, C. Cheng, Effect of different thermal schedules on ductility of microalloyed steel slabs during continuous casting, Metals (Basel), 9 (2019) 1-14, doi:10.3390/met9010037

${ }^{51}$ J. Konrádyová, M. Longauerová, P. Jonšta, Z. Jonšta, S. Longauer, V. Girman, M. Vojtko, A. Bořuta, M. Matvija, M. Fujda, J. Dobrovská, Hot Ductility of TiNb IF Steel Slab after Hot Torsion Testing, Metals (Basel), 9 (2019) 752, doi:10.3390/met9070752

${ }^{52}$ A. J. DeArdo, Niobium in modern steels, Int. Mater. Rev., 48 (2003) 371-402, doi:10.1179/095066003225008833

${ }^{53}$ C. A. D. Rodrigues, G. Tremiliosi-filho, Effect of titanium nitride (TiN) on the corrosion behavior of a supermartensitic stainless steel, Materials and Corrosion, (2019) 28-36, doi:10.1002/maco. 201810289

${ }^{54}$ M. Lee, J. Park, Synergistic Effect of Nitrogen and Refractory Material on TiN Formation and Equiaxed Grain Structure of Ferritic Stainless Steel, Metall. Mater. Trans. B. 49 (2018) 877-893, doi:10.1007/s11663-018-1218-7

${ }^{55}$ C. Capurro, C. Cicutti, Analysis of titanium nitrides precipitated during medium carbon steels solidification, Journal of Materials 


\section{J. BURJA et al.: NITROGEN AND NITRIDE NON-METALLIC INCLUSIONS IN STEEL}

Research and Technology, 7 (2018) 342-349, doi:10.1016/j.jmrt 2018.04.010

${ }^{56}$ J. Jang, S. Seo, J. Han, D. Kim, Y. Kang, J. Pak, Reassessment of $\mathrm{TiN}(\mathrm{s})=\mathrm{Ti}+\mathrm{N}$ Equilibration in Liquid Iron, ISIJ Int., 55 (2015) 2318-2324

${ }^{57}$ Z. Chen, M. Li, X. Wang, S. He, Q. Wang, Mechanism of Floater Formation in the Mold during Continuous Casting of Ti-Stabilized Austenitic Stainless Steels, 2019

${ }^{58}$ S. K. Kim, H. Suito, R. Inoue, Effect of Multi-phase Oxide Particles on TiN Crystallization and Solidification Structure in Ti-Added Ferritic Stainless Steel, ISIJ Int., 52 (2012) 1935-1944, doi:10.2355/ isijinternational.52.1935

${ }^{59}$ S. N. Lekakh, J. Ge, V. Richards, R. O’Malley, J. R. TerBush, Optimization of Melt Treatment for Austenitic Steel Grain Refinement,
Metall. Mater. Trans. B Process Metall. Mater. Process. Sci., 48 (2017) 406-419, doi:10.1007/s11663-016-0832-5

${ }^{60}$ R. Inoue, T. Ariyama, H. Suito, Thermodynamics of Zirconium Deoxidation Equilibrium in Liquid Iron by EMF Measurements, ISIJ Int., 48 (2008) 1175-1181, doi:10.2355/isijinternational.48.1175

${ }^{61}$ A. R. B. Maia, C. R. Guinâncio, R. L. Germano, P. R. Rios, I. de S. Bott, Use of Zirconium in Microalloyed Steels, Adv. Mater. Res., 15-17 (2009) 834-839, doi:10.4028/www.scientific.net/amr.1517.834

${ }^{62}$ T. N. Baker, Role of zirconium in microalloyed steels: a review, Mater. Sci. Technol., 31 (2014) 265-294, doi:10.1179/1743284714y. 0000000549 